\title{
THE TERTIARY AMINO EFFECT IN HETEROCYCLIC SYNTHESIS : MECHANISTIC AND COMPUTATIONAL STUDY OF THE FORMATION OF SIX-MIMMBERED RINGS
}

\author{
L.C. GROENEN," W. VERBOOM,a W.H.N. NIJUIS,a D.N. REINHOUDT,"a \\ G.J. VAN HUMMEL' and D. FEIL"b
}

Laboratories of Prganic Chemistry and bChemical Physics, University of Twente, P.O. Box 217, 7500 AE Enschode, The Netherlands

(Received in UK 7 April 1988)

\begin{abstract}
The mechanism of the ring closure of [2-(1-pyrrolidinyl)phenylmethylene]propanedinitrile (2a) to 1,2,3,3,4,5-hexahydropyrrolo[1,2-a]quinoline-4,4-dicarbonitrile (3a) has been studied by kinetic mensurements using 'H-NMR epectroacopy. It could be shown that the rate-determining step consigts of an intramolecultr 1,5 hydrogen transfer, which is accompaniod by charge separtition within the molecufe. The calculated (AM1) and experimental (X-ray) molecular structure of 22 are in fairly good agreement. In the pround state geometry a 1,5 hydrogen transfer will most likely take place suprafecially. Subequent rotation of the former vinyl group and C-C-bood formation, leading to a six-membered ring, also take place in a stereochemically defined way.
\end{abstract}

Tertiary anilines that bear an ortho substituent containing a $\pi$-bond can be used to synthesize nitrogen containing heterocycles. The reactions of these tertiary anilines have been generalized under the name "tert-amino effect" and have been reviewed a number of years ago by Meth-Cohn and Suschitziry. ${ }^{1}$ In this review reactions of compounds 1 are described in which $A=B$ contains at lesst one heteroatom. In our laboratories we have extended these reactions to compounds 1 in which $A=B$ constitutes a vinyl group. The type of reaction that occurs upon heating depends on the substituents of the vinyl group. ${ }^{23}$ It was sbown that when the B-carbon atom of the vinyd moiety bears two electron-withdrawing groups, e.g. CN or COOR (2), ring closure to a six-membered ring occurs and compounds 3 are formed. ${ }^{2}$ In a previous paper we have deacribed the self-reproduction of chirality that was observed when compound $2 \mathrm{a}$, in which the vinylic hydrogen atoon is replaced by a methyl group and the amino group is the (S)-(-)-2-(methaxymethyl)pyrrolidinyl moiety, is cyclized. These results could be explained by assuming the following mochanism for this reaction (Scheme I): in the conformation in which the vinyl moiety points away from the amino group a sigmatropic $[1,5]-\mathrm{H}$ shift takes plece. The migrating hydrogen atom $\mathrm{H}_{\mathrm{a}}$ remains at the same face of the molecule and a dipolar intermediate (4) is formed. Subsequently, the former vinyl group rotates around its bond to the phenyl moiety, thus enabling bond formation between the two

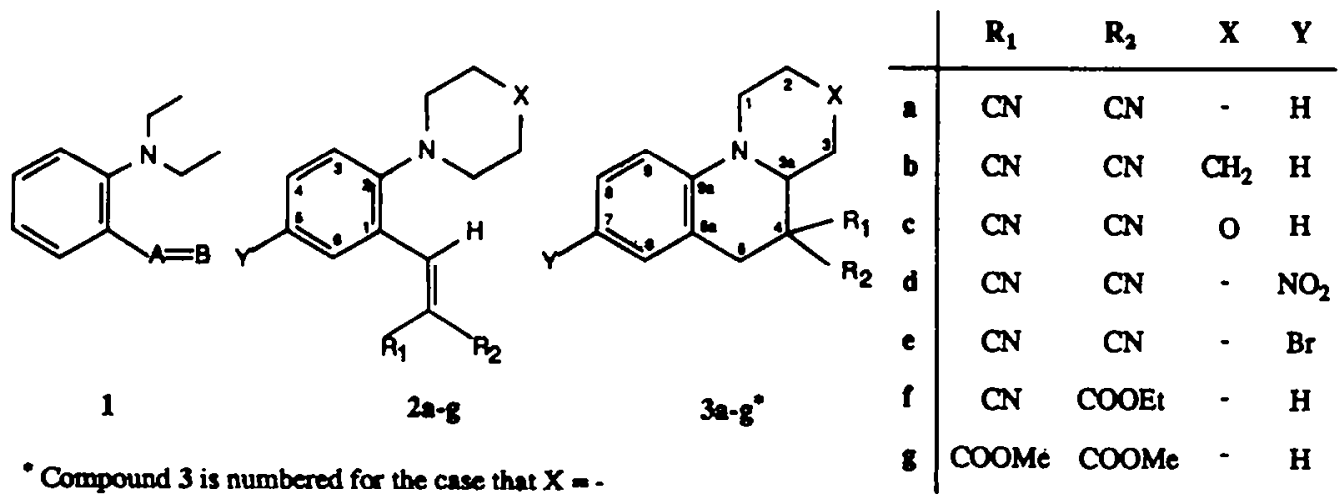




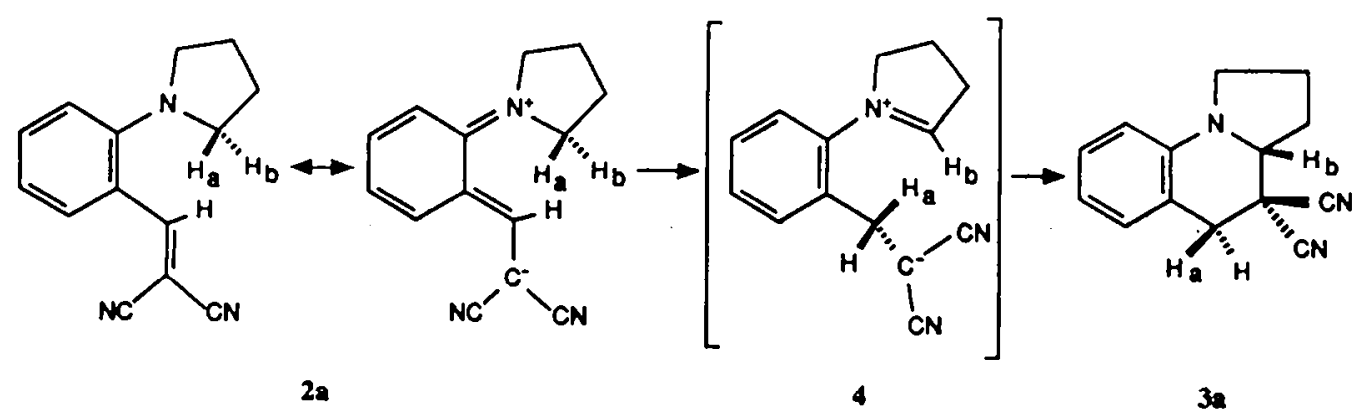

Scheme I

oppositely charged carton atoms to take place, resulting in the formation of the six-membered ring.

In this paper we present the results of a detailed kinetic study of the cyclization of compounds 2 . Besides having determined the kinetic parameters of the ring closure reaction of $2 \mathrm{a}$, we have investigated the influence on the reaction rate of different electron-withdrawing groups in the vinyl moiety, of different amino groups, of substituents at the 7-position of the aromatic ring. and also of the solvent used. In an attempt to acquire information on the starting conformation and the pathway of the hydrogen transfer, we have performed semi-empirical quantum chemical calculations on the parent molecule $2 \mathrm{a}$.

\section{RESULTS AND DISCUSSION}

\section{Synthesis of the surting maxerials and af their cyclization products}

Compounds $2 a-c$ and 28 were synthesized via a Knoevenagel condensation of the appropriate 2-(N,N-dialkylnmino)benzaldehyde with malononitrile and dimethyl malonate, respectively, following the procedure described earlier. ${ }^{2}$ Compounds $2 \mathrm{~d}$ and $2 \mathrm{f}$ were synthesized in an analogons way, using 5-nitro2-(1-pytrolidinyl)benzaldehyde ${ }^{5}$ and malononitrilc, or 2-(1-pyrrolidinyl)benzaldehyde and ethyl cyanoucetate as the starting materials, respectively. In the case of $2 f$ exclusively the $E$-isomer is formed, as can be judged from the chemical shift of the vinylic proton at $\delta=8.55$ in the ${ }^{1} \mathrm{H}-\mathrm{NMR}$ spectrum. This is in full agreement with earlies published results of investigations on the stereochemistry of the Knoevenagel condensation. ${ }^{6}$ Compound 2e was prepared directly from 2a in quantitative yield by bromination with NBS in DMF at room temperature.

Upon heating in refluxing 1-butanol all compounds 2 afforded the ring closed products 3 . In the case of $2 f$ ring closure could in principle give two diastereomeric compounds, due to the introduction of an extra asymmetric center upon cyclization. The cyano group can either be on the same or on the opposite face of the molecule relative to the bridge-bead hydrogen atom. 'H-NMR and ${ }^{13} \mathrm{C}-\mathrm{NMR}$ spectroscopy reveal that only one diastereomer is formed. It is, however, not possible to judge which of the two diastereomers is formed. Therefore

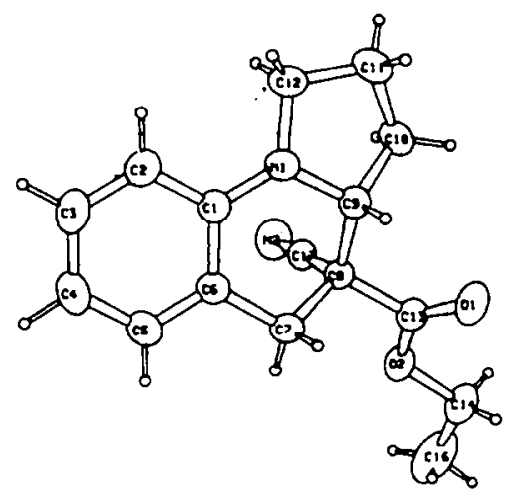

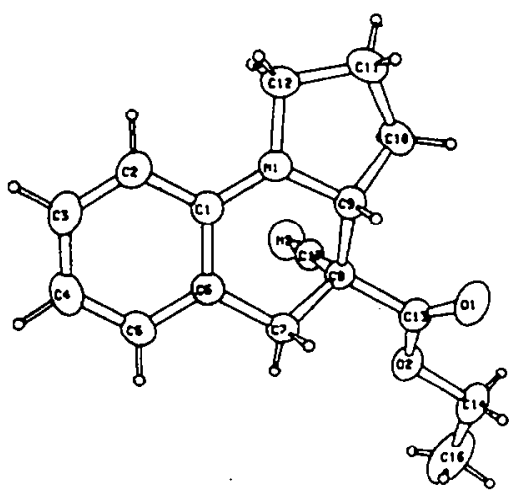

Figure 1. Stereoscopic view of the crystal structure of 38 
we resolved the crystal structure of the ring closed product $3 f$ using $X$-ray spectroscopy. Figure 1 shows clearly that the cyano group is on the opposite face relative to the bridge-head hydrogen atom. This implies that in the time between hydrogen migntion and C-C-bond formation the B-carbon atom bearing the cyano and the ester group does not rotate anound is bond to the $\alpha$-carbon atom.

\section{Kinetic Experiments}

The reactions were monitored using ${ }^{1} \mathrm{H}-\mathrm{NMR}$ spectroscopy. All reactions were cartied out in DMSO-df. Measurement of the rate of reaction of $2 \mathrm{a}$ at seven different temperanures in the range of 66.1 to $92.8^{\circ} \mathrm{C}$ gave the following activation parameters of the reaction (at $90.0^{\circ} \mathrm{C}$ ) : $\Delta H^{*}=22.2 \pm 0.4 \mathrm{kcal} \mathrm{mol}^{-1}, \Delta S^{*}=-12.0 \pm 1.1 \mathrm{cal}$ $\mathrm{mol}^{-1} \mathrm{~K}^{-1}$ and $\Delta \mathrm{G}^{\prime \prime}=26.6 \pm 0.8 \mathrm{kcal}^{\prime-1}$. The value of $\Delta \mathrm{H}^{*}$ is very low in comparison with activation enthalpies for other sigmatropic $[1,5]-\mathrm{H}$ shifts, especially when we consider that in the transition state of this hydrogen shift the conjugation in the benzene ring must be at least partially destroyed. Indeed, Wehrli et al.? have found that the $E / Z$-isomerization of 2-(1-propenyl)toluenes, which could take place via two consecutive $[1,5]-\mathrm{H}$ shifts as in the case of the 2-(1-propenyl)anilines and -phenols, has such a high activation enthalpy ( $\Delta \mathrm{H}^{*}$ $=49.2 \mathrm{kcal} \mathrm{mol}^{-1}$ in decane at $368^{\circ} \mathrm{C}$ ), that a biradical mechanism might be operative instead It seems therefore unlikely that in our case the rate-determining step consists of a sigmatropic $[1,5]-\mathrm{H}$ shif. This conclusion was strengthened by the observation that the non-aromatic compound 8 reacts much slower than $2 a .^{10}$ This clearly indicates that the aromatic part of the molecule is kept intact during the reaction and that another mochanism must be operative.

To ascertain if a hydrogen atom migrates at all in the rate-determining step, we determined the deuterium kinetic isotope effect of the resction. For this purpose we synthesized the tetradeuterated compound 6, starting from 2-fluorobenzaldehyde via a nucleophilic substitution ${ }^{12}$ with pyrrolidine-2,2,5,5-d ${ }_{4}^{13}$ to give 5 , followed by a Knoevenagel condensation with malononitrile, analogous to the synthesis of $2 a^{2}$ We measured a kinetic isotope effect of $3.0 \pm 0.3$ at $91.2{ }^{\circ} \mathrm{C}$ in DMSO- $d_{6}$. Although this kinetic isotope effect is the sum of a primary and a secondary binetic isotope effect, its magnitude is a strong indication that in the rate-determining step of the reaction migration of a hydrogen atom does take place.

From the ${ }^{1} \mathrm{H}$-NMR and mass spectra of the ring closed compound 7 it is clear that during the cyclization of 6 no deuterium is lost from the substrate. This definitely proofs that the hydrogen (deuterium) migration is an intramolecular process.<smiles>[2H]C1([2H])CCC([2H])([2H])N1c1ccccc1C=O</smiles>

5<smiles>[2H]C1([2H])CCC([2H])([2H])N1c1ccccc1C=C(C#N)C#N</smiles>

6<smiles>[2H]C1c2ccccc2N2C([2H])([2H])CCC2([2H])C1(C#N)C#N</smiles>

7<smiles>N#CC(C#N)=CC1=C(N2CCCC2)CCCC1</smiles>

8

When the polar solvent DMSO-d is replaced by the apolar woluene-d, the reaction rate decreases by a factor of about 150. This rather drastic solvent effect strongly indicates that the transition state of the ratedetermining step is highly polar in comparison with the ground state of $2 \mathrm{a}$. In the apolar tolvene-d a polar molecule will be less solvated and stabilized than in DMSO-d6. Assuming that the mochenism of the reaction is the same in both solvents, the slower reaction in the apolar tolvene-d must be due to a leas favourable solvation of the transition stave relative to the ground state than in the polar solvent DMSO-do. This indicates that charge separation takes plece in the mite-determining step.

The effects of variations in the structure of 2 on the reaction rate in DMSO-d are summarized in Table 1. Replacement of one or both of the cyano groups by the less electron-withdrawing ester groups (2f and 28) decretuses the reaction rate by factors of 14 and 94 , respoctively. This can be explained in terms of less delocalization and anbilization of a partial negative charge on the p-carbon atom of the vinyl group in the transition state. 
Table 1. Rate constants of the ring closure reactions of compounds $28-8$ and 6

\begin{tabular}{|c|c|c|c|}
\hline compound & solvent & $\begin{array}{c}\text { temperature } \\
\left({ }^{\circ} \mathrm{C}\right)\end{array}$ & $\begin{array}{c}\text { rate comatant } \\
\left(10^{-4} \text { rec-1) }\right.\end{array}$ \\
\hline $2 \mathrm{a}$ & toluene-d $_{6}$ & 93 & $0.067 \pm 0.005$ \\
$2 \mathrm{a}$ & DMSO-d $_{6}$ & 90.4 & $8.5 \pm 0.3$ \\
$2 \mathrm{~b}$ & DMSO-d $_{6}$ & 90.3 & $4.9 \pm 0.5$ \\
$2 \mathrm{c}$ & DMSO-d $_{6}$ & 92 & $0.19 \pm 0.05$ \\
$2 \mathrm{~d}$ & DMSO-d $_{6}$ & 90.9 & $0.29 \pm 0.03$ \\
$2 \mathrm{e}$ & DMSO-d $_{6}$ & 90.9 & $8.1 \pm 0.7$ \\
$2 \mathrm{f}$ & DMSO-d $_{6}$ & 90.7 & $0.60 \pm 0.02$ \\
$2 \mathrm{~g}$ & DMSO-d & 89 & $0.078 \pm 0.010$ \\
6 & DMSO-d & 91.2 & $2.9 \pm 0.2$ \\
\hline
\end{tabular}

In the same way introduction of the strongly electron-withdrawing nitro group (2d) docreases the reaction rate by a factor of 30, due to destabilization of the posidive charge on the nitrogen atom of the amino substituent in the transition state. The effect of a bromo substituent (2e) is marginal, as it is both an (inductive) electron-withdrawing group and a (mesomeric) electron-donating group.

Changing the amino group from pyrrolidinyl to piperidinyl or morpholinyl (2a, 2b, and 2c) docresses the reaction rate by factors of 1.7 and 50 , respectively. This can be explained in terms of decreased overlap of the lone pair of nitrogen with the benzene ring, ${ }^{14}$ which rendess delocalization of the positive charge on the nitrogen atom in the transition state less effective. In the case of morpholine, the transition state is even more destabilized by the presence of an electron-withdrawing oxygen atom in the ring.

\section{Semi-empirical quantum chemical calculations}

In order to gain more insight in the stereochemical course of the reaction, we performed some semi-empirical quantum chemical calculations on the ground state of molecule $2 \mathrm{a}$ and on a probable reaction path. The calculations were carried out with the AMPAC-programme. 15 The AM1-Hamilionian was chosen for all calculations, as it seemed superior to both the MINDO/3- and the MNDO-Hamiltonian. ${ }^{16}$

The structure of the ground state of compound $2 a$ was optimized and compared with the structure found by $X$-ray analysis (Figure 2 and Table 2). Pronounced differences between the calculuted and experimental souctare are found in the puckering of the benzene ring and the pyrrolidinyl ring, and in the dihedral angle between the benzene ring and the vinyl moiety. Both rings are calculared too flat in comparison with the observed structure. Calculated bond lengths and bond angles are in reasonable agreement with the experimental values. Bonds to hydrogen atoms are invariably calculated $0.10-0.15 \AA$ longer than those found in the X-ray structure, reflecting partly the known fact that hydrogen bond lengths obtained by $X$-ny spectroscopy are on an average $0.09 \AA$ too short. In the pyrrolidinyl ring the C-C-bond lengths are calculated to be longer and the C-C-C-angles to be larger than in the experimental structure. It seems that the calculated steric interactions in the five-membered ring are relaxed by expanding, instead of bending or puckering the ring. This calculation of a wrong seometry might well be caused by the neglect of the throe- and four-center two-electron integrals in the evaluntion of the electronic energy of the molocule, which are especially importunt in small rings. The fact that the vinyl moiety is rocated further away from coplanarity with the benzene ring in the calculated structure than in the $X$-ray structure, might partly be explained by crystal packing factors, in addition to the obvious errors due to simplifications in the calculations.

We also tried to locate a transition state for the migration of a hydrogen atom from $\mathrm{C}_{10}$ to $\mathrm{C}_{11}$ (atom numbering according to Figure 2). On pulling a hydrogen atom from $C_{10}$ to $C_{11}$ we noted that in the molecule charge separation takes place, thus lending support to the interpretation of the results of the kinetic measurements. We could, however, not locate a transition state on this reaction path. We are well aware of the 


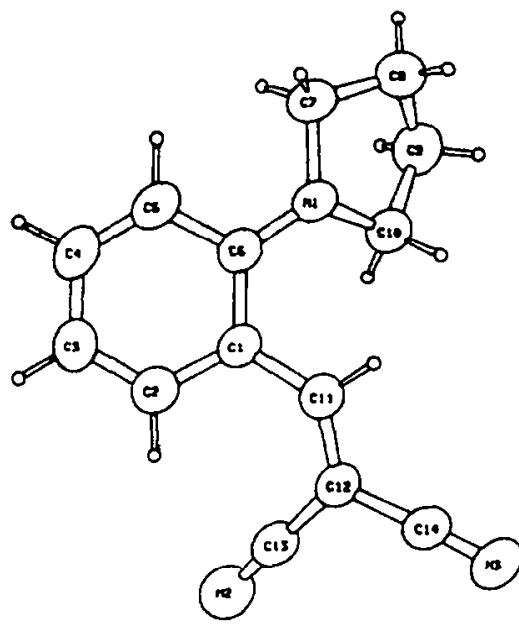

a

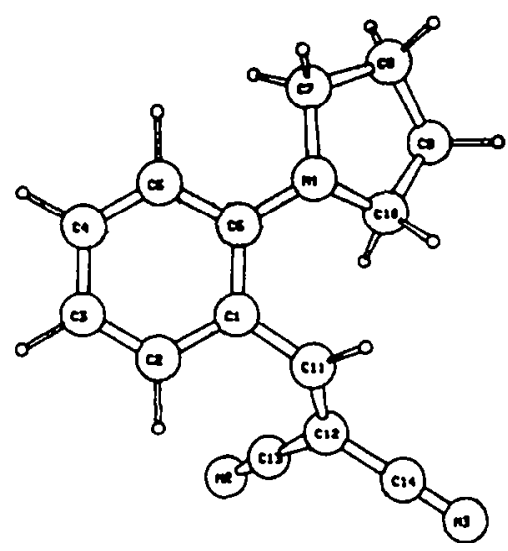

b

Figure 2. ORTEP 23 drawings of the crystal structure (a) and the calculated stucture (b) of $2 a$

Table 2. Selected geometry parameters of the observed and of the calculated molecular structure of $2 a$

\begin{tabular}{|c|c|c|c|c|c|c|c|c|}
\hline \multicolumn{3}{|c|}{ bond lengths (A) } & \multicolumn{3}{|c|}{ bond angles (o) } & \multicolumn{3}{|c|}{ dihedral angles $\left({ }^{\circ}\right)$} \\
\hline & $X$-ray & AM1 & & $X$-ray & AM1 & & $X$-ray & AMl \\
\hline$C_{1} C_{2}$ & 1.408 & 1.405 & $c_{1} C_{2} C_{3}$ & 122.5 & 121.6 & $C_{1} C_{2} C_{3} C_{4}$ & -1.1 & -0.6 \\
\hline$c_{2} c_{3}$ & 1.364 & 1.386 & $C_{2} C_{3} C_{4}$ & 118.7 & 119.1 & $C_{2} C_{3} C_{4} C_{5}$ & 3.9 & 1.7 \\
\hline$c_{3} c_{4}$ & 1.388 & 1.396 & $c_{3} c_{4} c_{3}$ & 121.3 & 120.7 & $c_{3} c_{4} c_{5} c_{6}$ & 0.1 & 0.0 \\
\hline $\mathrm{C}_{4} \mathrm{C}_{3}$ & 1.361 & 1.386 & $\mathrm{C}_{4} \mathrm{C}_{5} \mathrm{C}_{6}$ & 121.4 & 121.5 & $c_{1} C_{6} C_{5} C_{4}$ & -6.8 & -2.8 \\
\hline$c_{5} c_{6}$ & 1.419 & 1.423 & $c_{1} c_{6} c_{5}$ & 117.2 & 117.3 & $c_{2} c_{1} c_{6} c_{5}$ & 9.2 & 3.9 \\
\hline$c_{1} c_{6}$ & 1.428 & 1.426 & $C_{2} C_{1} c_{6}$ & 118.3 & 119.8 & $c_{3} C_{2} c_{1} c_{6}$ & -5.5 & -2.3 \\
\hline $\mathbf{N}_{1} \mathrm{C}_{6}$ & 1.358 & 1.400 & $N_{1} C_{6} C_{1}$ & 123.2 & 122.6 & $N_{1} C_{6} C_{1} C_{2}$ & -171.2 & -180.0 \\
\hline $\mathrm{N}_{1} \mathrm{C}_{7}$ & 1.475 & 1.463 & $C_{6} N_{1} C_{7}$ & 120.2 & 118.5 & $C_{7} N_{1} C_{6} C_{1}$ & -178.5 & 168.7 \\
\hline$C_{7} C_{8}$ & 1.502 & 1.536 & $N_{1} C_{7} C_{1}$ & 103.9 & 108.3 & $C_{6} N_{1} C_{7} C_{8}$ & -171.4 & -153.7 \\
\hline$C_{8} C_{9}$ & 1.502 & 1.522 & $C_{7} C_{7} C_{9}$ & 103.1 & 105.8 & $N_{1} C_{7} C_{1} C_{9}$ & 33.0 & 14.1 \\
\hline$C_{9} C_{10}$ & 1.511 & 1.538 & $C_{8} C_{9} C_{10}$ & 103.4 & 105.9 & $C_{7} C_{1} C_{9} C_{10}$ & -40.1 & -12.4 \\
\hline \multirow[t]{3}{*}{$N_{1} C_{10}$} & 1.468 & 1.460 & $N_{1} C_{10} C_{9}$ & 103.8 & 108.8 & $\mathrm{~N}_{1} \mathrm{C}_{10} \mathrm{C}_{9} \mathrm{C}_{t}$ & 31.4 & 6.6 \\
\hline & & & $C_{7} N_{1} C_{10}$ & 110.1 & 109.3 & $\mathrm{C}_{6} \mathrm{~N}_{1} \mathrm{C}_{10} \mathrm{C}_{9}$ & 145.3 & 144.8 \\
\hline & & & $C_{6} N_{1} C_{10}$ & 125.4 & 120.6 & $C_{10} N_{1} C_{6} C_{1}$ & 27.4 & 29.5 \\
\hline$C_{1} C_{11}$ & 1.436 & 1.451 & $C_{6} C_{1} C_{11}$ & 120.6 & 122.3 & $N_{1} C_{6} C_{1} C_{11}$ & 18.1 & 4.8 \\
\hline $\mathrm{C}_{11} \mathrm{C}_{12}$ & 1.357 & 1.355 & $c_{1} C_{11} c_{12}$ & 130.1 & 125.9 & $c_{6} C_{1} c_{11} c_{12}$ & -167.6 & -137.5 \\
\hline$C_{12} C_{13}$ & 1.427 & 1.423 & $C_{11} C_{12} C_{13}$ & 125.3 & 124.0 & $C_{1} C_{11} C_{12} C_{13}$ & 6.5 & 4.6 \\
\hline$C_{12} C_{14}$ & 1.435 & 1.425 & $c_{11} c_{12} c_{14}$ & 121.0 & 120.6 & $\mathrm{C}_{1} \mathrm{C}_{11} \mathrm{C}_{12} \mathrm{C}_{14}$ & -172.5 & -176.4 \\
\hline $\mathrm{N}_{2} \mathrm{C}_{13}$ & 1.145 & 1.163 & $N_{2} C_{13} C_{12}$ & 177.4 & 179.1 & $\mathrm{C}_{13} \mathrm{C}_{12} \mathrm{C}_{11} \mathrm{H}_{11}$ & -178.5 & -178.7 \\
\hline$N_{3} C_{14}$ & 1.140 & 1.163 & $N_{3} C_{14} C_{12}$ & 178.6 & 180.0 & $\mathrm{C}_{14} \mathrm{C}_{12} \mathrm{C}_{11} \mathrm{H}_{11}$ & 2.5 & 0.4 \\
\hline $\mathrm{C}_{11} \mathrm{H}_{11}$ & 0.96 & 1.108 & $C_{1} c_{11} H_{11}$ & 115.2 & 115.4 & $\mathrm{C}_{6} \mathrm{C}_{1} \mathrm{C}_{11} \mathrm{H}_{11}$ & 17.4 & 45.7 \\
\hline
\end{tabular}


fact that the described procedure (see also Experimental) is not a guaranteed way for finding a transition state. A more thorough search of the AM1 potential surface, however, seemed not appropriate, the more so as the important stabilization of the developing dipole by solvation is not sccounted for in the calculations. It is therefore also not at all certain that a transition state does exist on the AM1 potential surface of $2 a$.

The calculated and experimental structures of the ground state of $2 a$, in which the vinyl molety is more or less rotated away from coplanarity with the benzene ring, do give some clues for the stereochemical course of the reaction under investigation. When we look at Figure 2 ( $a$ or b) we see that in case of a hydrogen transfer from $\mathrm{C}_{10}$ to $\mathrm{C}_{11}$, the hydrogen atom below the plane of the molecule will be favoured over the other hydrogen atom bonded to $\mathrm{C}_{10}$. The migration of the first mentioned hydrogen atom will in this case most likely take place suprafacially, although it is not a sigmatropic $[1,5]-\mathrm{H}$ shift (vide supra). As the vinyl moiety is already partly rotated around $C_{1}-C_{11}$ when this hydrogen atom is migrating, is seems likely that further rotation of the vinyl moiety to enable bond formation berween $C_{10}$ and $C_{12}$, will proceed in the same direction. As $C_{10}$ and $C_{12}$ are oppositely charged this rotation will be very quick, leaving no time for $\mathrm{C}_{12}$ to rotate around its bond ro $\mathrm{C}_{11}$ (vide supra). In this way one enantiomer is formed with the hydrogen atom at $\mathrm{C}_{10}$ pointing upwards. In exactly the same way the other enantiomer can be formed, starting from the mirror image of the ground state, in which $\mathrm{C}_{13}-\mathrm{N}_{2}$ is pointing upwards instead of downwards.

\section{CONCLUSION}

The results of this kinetic study indicate that the first step in the reaction mechanism of the ring closure of [2-(1-pyrrolidinyl)phenylmethylene]propanedinitrile (2a) is an intramolecular 1,5 hydrogen transfer, although not a sigmatropic one. It seems likely, in view of the charge separation that takes place, that the migratiog hydrogen atom bears a partially negative charge. When we consider the geometry of the ground state of 2a, it seems probable that the hydrogen migration will occur suprafacially. Subsequent rotation of the former vinyl group will probably continue in the same direction as this group is already urned when the hydrogen migration takes place. The complete reaction is thus stereochemically well defined. This means that the results described earlier can be satisfactorily explained by this revised mechanism.

\section{EXPERIMENTAL}

M.ps were determined with a Reichert melting point apparatus and ar uncorrected. ${ }^{1} \mathrm{H}-\mathrm{NMR}$ spectra were reconded with a Bruker WP-80 spectrometer and ${ }^{13}$ C-NMR spectra were recorded with a Nicalet MT 200 spectrometer, using $\mathrm{CDCl}_{3}$ as a solvent with $\mathrm{Me}_{4} \mathrm{Si}$ as an internal standsed. Mass epectra wero obthined with a Varian MAT 311A spoctrometer and IR spoctra with a Perkin-Bimer 257 spectrophotometer. Blemental analyses were carried out by A.M. Christenhusz of the Labosatory of Chemical Anslysis of the Univerity of Twente.

Compounds $2 a-c, g$ and $3 a-c s$ were prepared as described earlier. 2

2-Fluorobenzaldehyde was purchaed from Janseen Chimica.

2-(1-Pyrrolldinyl-2,2,5,5-djbenzaldebyde (5). To a soln of 2-flporobenzaldehyde $(2.48 \mathrm{~g}, 0.020 \mathrm{~mol})$ and $\mathrm{K}_{2} \mathrm{CO}_{3}(2.78 \mathrm{~g}, 0.020 \mathrm{~mol})$ in DMF $(10 \mathrm{ml})$ was added pyrrolidine-2,2,5,5-d4 13 (1.50 $\left.\mathrm{g}, 0.020 \mathrm{~mol}\right)$. The reaction mixture wis refluxed for $S$ hr under $N_{2}$. After cooling the mixture was poored in BtOHActwater (1:1, 20 $\mathrm{ml})$. The water layer was extracted with $\mathrm{BtOAc}(3 \times 20 \mathrm{ml})$. The combined extructs wero washed with su NH, $\mathrm{Cl}$ aq $(50 \mathrm{ml})$, dried $(\mathrm{MgSO})$ and evaporated under reduced pressure. Distillation afforded the pure 7 (17\%), b.p. $122^{\circ} \% .03 \mathrm{~mm}$. ${ }^{1} \mathrm{H}-\mathrm{NMR}$ 8: $10.08(\mathrm{~s}, 1 \mathrm{H}, \mathrm{CHO}), 7.9-7.6(\mathrm{~m}, 1 \mathrm{H}, \mathrm{H}-6), 7.5-7.2(\mathrm{~m}, 1 \mathrm{H}, \mathrm{H}-4), 6.9-6.6(\mathrm{~m}, 2 \mathrm{H}, \mathrm{H}-3$ and $\mathrm{H}-5), 1.94\left(\mathrm{~s}, 4 \mathrm{H}, \mathrm{CH}_{2}\right)$.

General procedure for the preparation of $2 d$ and 6 . To a soln of 5-nitro-2-(1-pyrrolidinyl)benzaldehyde or $5(10 \mathrm{mmol})$ in tolvene $(15 \mathrm{mi})$ malononitrile $(0.66 \mathrm{~g}, 10 \mathrm{mmol})$ was addod. In the case of $2 \mathrm{~d}$ : few drops of piperidine were added as base. After stiming for $1 \mathrm{hr}$ at room temp the solvent was removed under reduced pressure. The residue was rocrystullizod from methenol to give the pure compound.

[5-Nitro-2-(1-pyrrolidinyl)phenylmethylene]propanedinitrile (2d). Yield $9 \% \%$, orange-brown needles, m.p. 165-168. ${ }^{1} \mathrm{H}-\mathrm{NMR}$ 6: 8.53 (d, $\left.1 \mathrm{H}, J=2.7 \mathrm{~Hz}, \mathrm{H}-6\right), 8.18$ (dd, $1 \mathrm{H}, J=9.5$ and $\left.2.7 \mathrm{~Hz}, \mathrm{H}-4\right), 8.03(\mathrm{~s}, 1 \mathrm{H}$, $=\mathrm{CH}), 6.85(\mathrm{~d}, 1 \mathrm{H}, J=9.5 \mathrm{~Hz}, \mathrm{H}-3), 3.6-3.3(\mathrm{~m}, 4 \mathrm{H}, \mathrm{NCH}), 2.3-1.9(\mathrm{~m}, 4 \mathrm{H}, \mathrm{CH}){ }^{13} \mathrm{C}-\mathrm{NMR}$ 8: $158.9(\mathrm{~d}, \mathrm{CH})$, $152.8(\mathrm{~s}, \mathrm{C}-2), 137.8(\mathrm{~s}, \mathrm{C}-5), 128.5$ and $127.6(\mathrm{~d}, \mathrm{C}-4$ and $\mathrm{C}-6), 127.8(\mathrm{~s}, \mathrm{C}-1), 115.4$ and $113.6(\mathrm{~s}, \mathrm{CN}), 114.5$ $(\mathrm{d}, \mathrm{C}-3), 82.0[\mathrm{~s},=\mathrm{C}(\mathrm{CN})], 53.0\left(\mathrm{t}, \mathrm{NCH}_{2}\right), 26.0\left(\mathrm{~h} \mathrm{CH}_{2}\right)$. IR $(\mathrm{KBr}) \mathrm{cm}^{-1}: 2232(\mathrm{CN}), 1606(\mathrm{C}=\mathrm{C})$. MS: $\mathrm{m} / \mathrm{e}$ 268.096 $\left(\mathrm{M}^{+}\right.$, calc.: 268.096). (Found: C, 62.56; H, 4.53; N, 20.90. Calc. for $\mathrm{C}_{14} \mathrm{H}_{12} \mathrm{~N}_{4} \mathrm{O}_{2}(\mathrm{M}, 268.277)$ : C. $62.68 ; H, 4.51 ; N, 20.88 \%$.)

[2-(1-Pyrrolidiny]-2,2,5,5-d)phenylmethylene]propanedinitrile (6). Yield quant., red crystals, m.p.

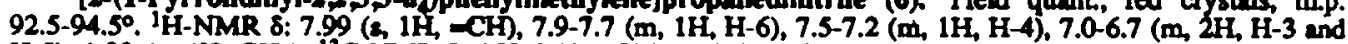
$\mathrm{H}-5), 1.99\left(\mathrm{~s}, 4 \mathrm{H}, \mathrm{CH}_{2}\right){ }^{13} \mathrm{C}-\mathrm{NMR} 8: 159.6(\mathrm{~d}, \mathrm{CH}), 151.6(\mathrm{~s}, \mathrm{C}-2), 134.6$ (d, C-4), 129.9 (d, C-6), 119.0 (s, $\mathrm{C}-1$ ), 118.5 and 115.5 (d, C-3 and C-5), 114.9 and $113.2(3, \mathrm{CN}), 77.1\left[3,-C(\mathrm{CN})_{2}\right], 52.5$ (quintel, NCD $), 25.6$ $\left(\mathrm{t}, \mathrm{CH}_{2}\right.$ ). IR $(\mathrm{KBr}) \mathrm{cm}^{-1}$ : 2218 and 2209 (CNN), 1606 (C-C). MS: m/e 227.135 QM , calc.: 227.136). (Found: C, 73.86; $H+D, 5.86 ; N, 18.59$. Calc. for $C_{14} H_{9} D_{4} N_{3}(M, 227.304): C, 73.98 ; H+D, 3.76 ; N, 18.49 \%$.)

[5-Bromo-2-(1-pyrrolidiayl)phenylmethjlene]propanedinitrile (2e). To a coli of $3 \mathrm{a}(1.12 \mathrm{~g}, 5 \mathrm{mmol})$ in DMF ( $5 \mathrm{ml}$ ) was added a soln of NBS $(0.89 \mathrm{~g}, 5 \mathrm{mmol})$ in DMF (15 ml). A A ter etiring for $24 \mathrm{hr}$ at room temp sat $\mathrm{NH}_{4} \mathrm{Cl}$ aq $(20 \mathrm{ml})$ was added to the soln and the mixure was exuncted with BtOAc $(3 \times 20 \mathrm{ml})$. The combined extracts were dried $\left(\mathrm{MgSO}_{4}\right)$ and evaporated under reduced pressure. The residue was recrystallized 
from mechanol to afford pere 2 (quant) as cange nedles, m.p. 139-1410. ${ }^{1} \mathrm{H}-\mathrm{NMR} .8: 7.82$ (c, 1H, -CH), 7.76 (d, $1 \mathrm{H}, J=2.2 \mathrm{~Hz}, H-6) .7 .36 \mathrm{fdd}, 1 \mathrm{H}, J=9.0 \mathrm{ed} 2.2 \mathrm{~Hz}, \mathrm{H}-4), 6.71$ (d, $1 \mathrm{H}, J=9.0 \mathrm{~Hz}, \mathrm{H}-3$ ), 3.4-3.1 (m, $4 \mathrm{H}$,

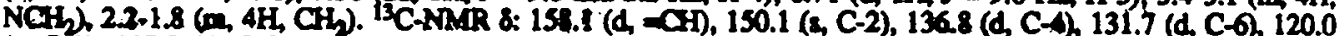

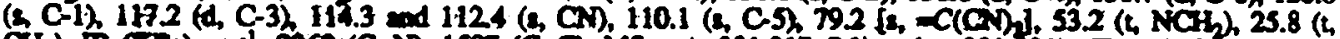

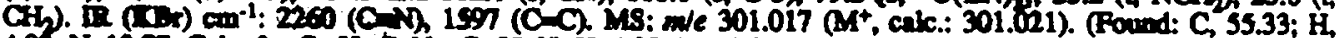

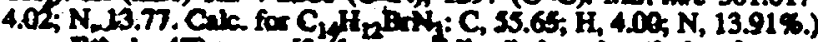

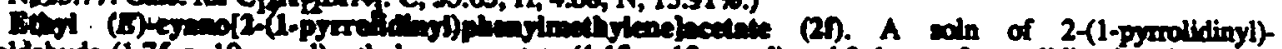

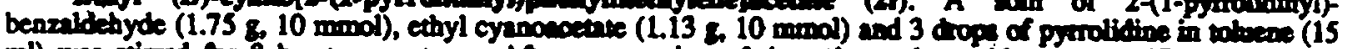

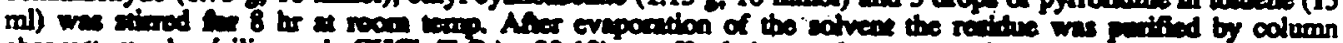

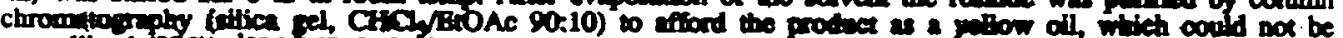
crysullized (9) $\%$ ). 'H-NMR 8: $8.35(\mathrm{~s}, 1 \mathrm{H}, \mathrm{CH}), 8.0-7.8(\mathrm{~m}, 1 \mathrm{H}, \mathrm{H}-6), 7.5-7.2(\mathrm{~m}, 1 \mathrm{H}, \mathrm{H}-0,7.0-6.7$ (m, 2H, $\mathrm{H}-3$ and $\mathrm{H}-5), 4.36(4,2 \mathrm{H}, \mathrm{J}=7.2 \mathrm{~Hz}, \mathrm{OCH}), 3.5-3.1(\mathrm{~m}, 4 \mathrm{H}, \mathrm{NCH}), 2.1-1.7(\mathrm{~m}, \mathrm{H}, \mathrm{CH}) \mathrm{L}, 39(\mathrm{c}, 3 \mathrm{H}, J=7.2$

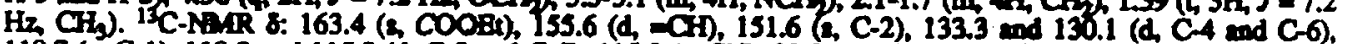
119.7 (8. C-1), 118.3 and $115.0(\mathrm{~d}, \mathrm{C}-3$ and $\mathrm{C}-5), 115.9(\mathrm{~s}, \mathrm{CN}), 99.0[\mathrm{~s}, \mathrm{C}(\mathrm{CN})(\mathrm{COO} 3 \mathrm{~A})], 62.2(\mathrm{~s}, \mathrm{OCH}), 53.0$ $\left(\mathrm{t}, \mathrm{NCH}_{2}\right), 25.8\left(\mathrm{t}, \mathrm{CH}_{2}\right), 14.2\left(\mathrm{q}, \mathrm{CH}_{3}\right)$. IR (KBr) cm$-1: 2220(\mathrm{CmN}), 1720(\mathrm{C}=0), 1599$ (C) C). MS: m/e 270.134 $\left(\mathrm{M}^{+}\right.$, calc. for $\left.\mathrm{C}_{1} \mathrm{H}_{\mathrm{i}} \mathrm{N}_{2} \mathrm{O}_{2}: 270.137\right)$.

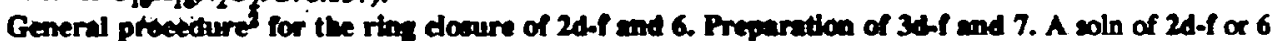
$(0.5 \mathrm{~g})$ in 1-butanol (10 m) whs refluxed for $20,4,6$, and $4 \mathrm{~b}$, repectively. $O$ o cooling a precipitate was formed, which was filtered off and recrysullized from methnol to affend the pure produet.

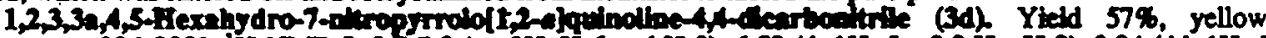
needles, m.p. 234-2390. 1H-NMR 8: $8.2-7.9$ (m, 24, H-6 and H-V), 6.58 (d, 1H, J = 8.8 Hz, H-9), 3.94 (dd, 1H, J

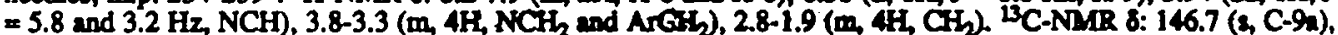
138.3 (s, C-7), 126.1 and 125.5 (d, C-6 and C-8), 113.9 and 113.2 (c, ON), 112.0 (2, C-5a), 111.1 (d, C-9), 63.0 (d. NCH), $48.4(\mathrm{t}, \mathrm{NCF}), 37.8\left(\mathrm{t}, \mathrm{ArCH}_{2}\right), 33.4$ (s, C(CN) $)_{2}, 29.9$ and $22.8\left(\mathrm{~h} \mathrm{CH}_{2}\right)$. IR (KBr) $\mathrm{cm}^{-1}: 2259$ (C=N). MS: m/e 268.097 $\mathrm{M}^{+}$, cutc.: 268.096). (Found: C, 62.00; $\mathrm{H}, 4.48 ; \mathrm{N}, 20.55$. Cile. for $\mathrm{C}_{14} \mathrm{H}_{12} \mathrm{~N}_{1} \mathrm{O}_{2}\left(\mathrm{M}_{4}\right.$ 268.277): C, 62.68; H, 4.51; N, 20.88\%.)

7-Bromo-1,2,3,3a,4,5-bexoly dropyrrolo[1,2-a]quinoline-4,4-dicarbonitrile (3t). Yield 84\%, colourless crystals, m.p. 172-173.50. 1 H-NMR 8: 7.4-7.1 (m, 2H, H-6 and H-8), 6.44 (d, 1H, J = 8.5 H. H-9), 3.77 (dd, $1 \mathrm{H}$, $J=7.7$ and $5.8 \mathrm{~Hz}, \mathrm{NCH}), 3.6-3.2(\mathrm{~m}, 2 \mathrm{H}, \mathrm{NCH}), 3.42(\mathrm{~s}, 2 \mathrm{H}, \mathrm{ACH}), 2.7-1.9\left(\mathrm{~m}, 4 \mathrm{H}, \mathrm{CH}_{2}\right)$. ${ }^{13} \mathrm{C}-\mathrm{NMMR}$ 8: 141.0 (s, C-9a), 132.0 and 131.4 (d, C-6 and C-8), 115.5, 114.6 and 112.7 (s, CS-a and CN), 113.8 (d, C-9), 109.3

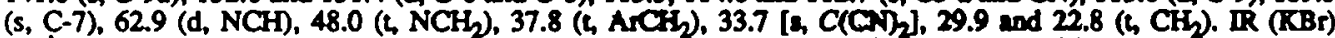
$\mathrm{cm}^{-1}: 2226$ (CmN). MS: m/e 301.020 (M+ calc.: 301.021). (Found: C, 55.58; H, 4.04; N, 13.93. Calc. for $\mathrm{C}_{14} \mathrm{H}_{12} \mathrm{BrN}_{3}(\mathrm{M}, 302.181)$ : C, 55.65; $\mathrm{H}, 4.00 ; \mathrm{N}, 13.91 \%$.)

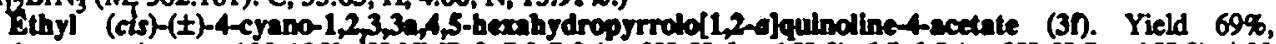
colourtess crystals, m.p. 123-1250. TH-NMR 8: 7.2-7.0 (m, 2H, H-6 and H-8), 6.7-6.5 (m, 2H, H-7 and H-9), 4.30 and $4.27\left(\mathrm{ABX}_{3}, 2 \mathrm{H}, J_{\mathrm{AB}}=-10.8, J_{\mathrm{AX}}=7.2, J_{\mathrm{ZX}}=7.1 \mathrm{~Hz} \mathrm{OCH}\right), 3.73$ (dd, $1 \mathrm{H}, J=8.2$ and $\left.5.8 \mathrm{~Hz}, \mathrm{NCH}\right)$, 3.6-3.2 (m, 4H, NCH, and $\left.\mathrm{ArCH}_{2}\right), 2.3-1.9(\mathrm{~m}, 4 \mathrm{H}, \mathrm{CH}), 1.31$ (dd, 3H, $\mathrm{J}=7.1$ and $7.2 \mathrm{~Hz}, \mathrm{CH}_{3}$ ). ${ }^{13} \mathrm{C}-\mathrm{NMMR}$ : $168.1(\mathrm{~s}, \mathrm{C}=0), 142.4(\mathrm{~s}, \mathrm{C}-9 \mathrm{e}), 129.0$ and 128.4 (d, C-6 and C-8), 116.6 and 115.9 (s, C-5n and $\mathrm{CN}$ ), 116.5 and 111.5 (d, C-7 and C-9), 63.1 (t, OCH h), 62.0 (d, NCH), 47.3 (t, NCF), 45.2 [s, C(CN)(COOBt)], 37.1 (t, $\left.\mathrm{ArCH}_{2}\right), 29.3$ and $23.2\left(\mathrm{t}, \mathrm{CH}_{2}\right), 14.1\left(\mathrm{q}, \mathrm{CH}_{3}\right)$. IR (KBr) cm-1: 2250 (O-N), 1742 (CO). $\mathrm{MS}: \mathrm{m} / \mathrm{l} 270.135 \mathrm{M}^{+}$, calc.: 270.137). (Found: $C, 70.97 ; \mathrm{H}, 6.94 ; \mathrm{N}, 10.27$. Calc. for $\mathrm{C}_{16} \mathrm{H}_{10} \mathrm{~N}_{2} \mathrm{O}_{2}(\mathrm{M}, 270.334): \mathrm{C}, 71.09 ; \mathrm{H}, 6.71 ; \mathrm{N}$, 10.36\%.)

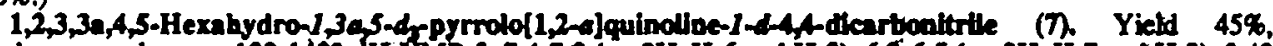
colouriess crystals, m.p. 132-1 220. H.NMR 8: 7.4-7.0 (m, 2H, H-6 and H-8), 6.96.5 (m, 2H, H-7 and H-9), 3.48 (d. $\left.1 \mathrm{H}, J_{\mathrm{HD}}=1.5 \mathrm{~Hz}, \mathrm{ACCHD}\right), 2.8-1.9(\mathrm{~m}, 4 \mathrm{H}, \mathrm{CH})$. ${ }^{3} \mathrm{C}-\mathrm{NMR}$ 8: 142.0 (s, C-9a), 129.2 and 129.0 (d, C-6 and $\mathrm{C}-8$ ), 117.3 and 112.2 (d, C-7 and C-9), 115.0, 113.4 and 113.0 (s, C-5n and CN), 64.9 (h, NCD), 47.2 (quintet,

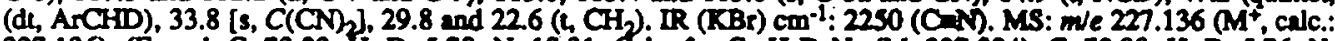
227.136). (Found: $C, 73.23 ; \mathrm{H}+\mathrm{D}, 5.78 ; \mathrm{N}, 18.31$. Caic. for $\mathrm{C}_{14} \mathrm{H}_{6} \mathrm{D}_{4} \mathrm{~N}_{3}\left(\mathrm{M}_{7} 227.304\right): \mathrm{C}, 73.98 ; \mathrm{H}+\mathrm{D}, 5.76 ; \mathrm{N}$, 18.49\%.)

Kinetic experinents. The kinetic mensurements were carled out using ${ }^{1} \mathrm{H}-\mathrm{NMR}$ spoctroscopy. As a probe for the progress of the reaction, the decreasing infegenl of the Aignal of the vinylit hydrogen atom was used. As internal reference signal the integnal of the abocption peat of triptyoepe at $8=5.60$ (D) used. All reactions were carried out in DMSO-d to aspure that the signal of the vinylic hydrogen atom did not coincide with the aromatic bydrogen atom signals. All measurements were performed on a Brater WP-80 spectrometer.

In a typical experiment the racting compound $(0.1 \mathrm{mmal})$ and tiptycene $(6.35 \mathrm{mg}, 0.025 \mathrm{mmol})$ were dissolved in bMSO-do $(0.5 \mathrm{ml})$. The sealed NMR-tube was pur in the thermostated probe and allowed to warm up to the desired temperanure. At fixed intervils spectur were reconded and internited. The temperuture was measured oace at the end of the reaction, using a thermocouple. The resction rate constant $k$ was calculated using a polysome fitting protrume.

All reactions followed fird onder binetics for at least two half lives. Compounds $2 d$ and $2 f$ mere masured a little shorter in time, approximately $1 \frac{1}{1}$ half lives. The results are mentioned in the text and are summarized in Table 1.

Semi-empirical quantum chenical calculation. The colculations were carried out with the AMPAC programme 15 on a VAX 8650 computer. The ground state of 2 w wis refined with respect to all 84 internal coordinates, uring the AM1-Humiltonien. The final gradient norm was 0.7.

The reaction path was simulated by pulling one of the hydroyen atoms at $C_{10}$ to $C_{11}$. At each step on the reaction path the distance between $\mathrm{C}_{11}$ and the migrating hydrogen atom was beld conetupt. Only part of the rest of the molecule was optimized at each step, the intermal coordinntes of the benzone ring with hydrogen atoms and of the hydrogen atoms of the pyrrolidinyl ring were also beld consint to reduce computution time.

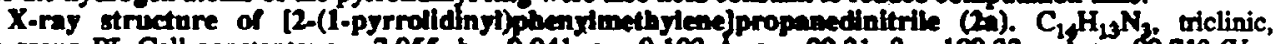
space group PT. Cell constants: a $=7.955, b=9.041, c=9.103 \mathrm{~K}, \alpha=99.21, \beta=109.32$ and $\gamma=99.71^{\circ} \mathrm{V}=$ $\left.592.3 X^{3}\right), Z=2, p_{c}=1.252 \mathrm{~cm}^{-3}$.

X-ray diffinction dan were collectod at $293 \mathrm{~K}$ on an Enraf-Nonius CAB4 single crystal diffinctometer, using Mo $\mathrm{K}_{\mathrm{a}}$ radition mosochomated by a gaphite crystal $(\lambda=0.71069 \mathrm{~A})$. The lemee pernometers were determined by refinement of 25 reflections with the leatesquares meahod. In conl, 2093 unique reflections were measured $(-10 \leq \mathrm{h} \leq 10,-12 \leq \mathrm{k} \leq 12,0 \leq 1 \leq 12)$ with the ape canning mode (maimum scen-speed $0.09^{\circ}$ $\sec ^{-1}$, scan-width $\left.1.0^{\circ}+0.34 \mathrm{tg} \theta\right)$. The maximam veriation in thec stanther reflections was $0.3 \%$. 
The stincture. was solved by direet method,24 and was refined wing the full-marix leact-cquares procedure, ${ }^{25}$ using 1459 reflections with I $>2$ F(I). All hydrogea atome wete locintod by difference Fourier mups.

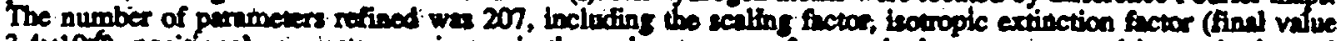

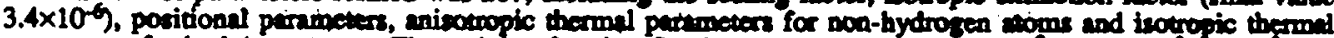

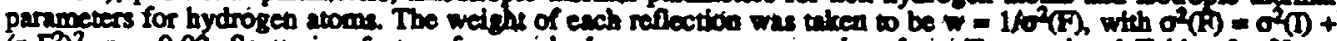
$\left(p . F^{2}\right)^{2}, p=0.02$. Scattering factors for nod-hydrogen anom were viben froin "Internutional Tables for. X-rny

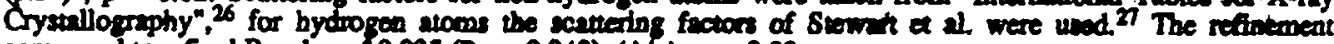
converged to a find $R$-vilue of $0.035\left(R_{w}=0.043\right)$, $(\Delta /)_{\text {max }}=0.03$.

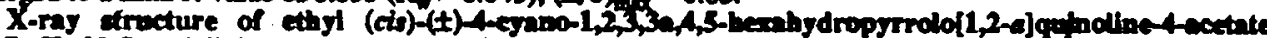
(3h), $\mathrm{C}_{16} \mathrm{E}_{18} \mathrm{~N}_{2} \mathrm{O}_{2}$ : triclinic, space group $\mathrm{PF}$ : $C$ ll constants: $2=10.150, b=8.988, c=8.357 \mathrm{~A}, \alpha=84.84, \beta=$ $72.67, \gamma=7.4 .03^{\circ}\left(V=699.4 \lambda^{3}\right) . Z=2, p_{c}=1.284 \mathrm{~cm}^{-3}$.

$X$-ray diffirction dats were collected a $293 \mathrm{~K}$ on a Philips PW1100 single crystal diffinctometer. The soul number of unique reflections was $4080(-13 \leq \mathrm{h} \leq 14,+12 \leq \mathrm{k} \leq 12,0 \leq 1 \leq 11)$, measured with the of 20 ectinning mode (muximam scan-speed $0.1^{\circ} \sec ^{-1}$, scan width $1.3^{\circ}+0.7 \mathrm{tg} \theta$ ). The maximum variation in three reanderd reflections was 2.3\%.

All methods were identical to those reported above for $2 \mathrm{a}$, using $\mathrm{p}=0.04$ in the weighing-schems. In the refinement of twe 254 parameter 2833 reflections were used with I $>30(\mathrm{I})$. The finul expinotion copfficient was $1.0 \times 10^{-6}$. The refinement comverged to $\& R$-value of $0.044\left(R_{w}=0.059\right)$. The three hydrogen atoms of the methyl group were badly charactarised probably dae to thermal motion.

Atomic coondinates and bond lengthe for both structures have been deposited with the Cumbridge Crystallographic Dat Centre. These cen be obenised on request trom The Diroctor, Cambridge Data Centre, University Chemical Laboritory, Lensfield Rond, Cambridge CB2 IEW, U.K.

Complete.lists of positional parameters for all atoms, anisotropte thermal parameters for heavy atoens and isotropic thermial parameters for hydrogen atoms, and list of bond lengths and bond anjles have been deposited as Supplementary Material with the Britisch Library Lending Division, Boston Spa, Wetherby, Weat Yorts LS23 7BQ, U.K.

Acknowledsements. This investigation was partly supponted by the Netherlands Foundation for Chemical Research (SON) with financial aid from the Netherlands Organization for Scientific Resenrch (NWO). The authors wrish to thank Dr. D.M.W. van den Ham and Dr. C. Huissoon for stimulating discussions on the theory and the result of the semi-empirical quentum chemical calculations.

\section{REFERENCES AND NOTES}

1. O. Meth-Cohn and H. Suschitzky, Aat, Heterocycl. Chem. 14, 211 (1972).

2. W. Verboom, D.N. Reinhoudt, R. Visser and S. Hurtem, J. Org. Chem. 49, 269 (1984).

3. W.C. Dijksman, W. Vertoom, R.M.M. Eg berink and D.N. Reinbroud, J. Org. Chem. 50, 3791 (1985).

4. W.H.N. Nijhuis, W. Verboom and D.N. Reinhoudt, J. Am. Chem. Soc. 109,3136 (1987).

5. D.B. Mobbs, H. Suschizzly and I.S. Millership, J. Chem. Soc. (C) 175 (1971).

6. J. Zabicky, J. Chem. Soc. 683 (1961).

7. R.H. Mirchell, Y.-H. Lai and R.Y. Williams, J. Org. Chem. 44, 4733 (1979).

8. C.W. Spangter, Chem. Rev. 76, 187 (1976).

9. R. Wehrli, H. Heimgartner, H. Schmid and H.-J. Hansen, Helv. Chim. Acta 60, 2034 (1977).

10. Cyclization of compound $8^{11}$ in refluxing 1-butanol took approximately 2 days, instead of the 2 hours neaded for compound $2 a$ under the same conditions (unpubbshed results).

11. H. Kurihara and H. Mishima, J. Heterocycl. Chem. 14, 1077 (1977).

12. K.B. Niewiadomsky and H. Suschitzky, J. Chem. Soc., Pertin Trans. 11679 (1975).

13. D. Rogic, M.F. Lautie, P. Dizabo and L.C. Leitch, J. Labelled Compd. 10, 655 (1974).

14. F. Effenberger, P. Fischer, W.W. Schoeller and W.-D. Stohrer, Tetrahedron 34, 2409 (1978).

15. "AMPAC", QCPE programme no. 506, Dewar Reseanch Oroup. Chemistry Department, University of Texas, Austin, Texas 78712 and IJ.P. Siewar, Seiler Research Labs, U.S. Air Force Academy, Colorado Springs, Colorado 80840 (1986).

16. AM1 bas been introduced ${ }^{17}$ as in improved version of MNDO, 18 which was in turn a suoceser of MINDO/3.19 We checked the performince of AM1 against those of MNDO and MINDOS on two selected problems. Optimization of the sterically crowded cisoid conformation of (Z)-1,3-pentadiene revesled that only AMl gave rensounble results. Both MDNDO/3 and MNDO prodicted a conformition in which the two double bonds are pearly perpendicular, whereas AMI arrived at a dihedral angle of $38^{\circ}$ between the two double bonds. This geometry is in reasonable agreconent with publisbod gat pinse structures of some sterically crowded conjugated dienes and trienes. ${ }^{20}$ Secondly, we calculited the

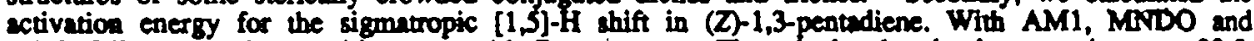
MINDO/3 we found a transition state with $\mathrm{C}_{2 x}$-symmetry. The calculated activation energies were 39.5, 57.0 and $45.4 \mathrm{kcal} \mathrm{mol}^{-1}$, respectively. The experimental vilue is $35.4 \mathrm{kcal} \mathrm{mol}^{-1}$. 1 The MINDO/3-value is nearly the same as the value ( $45.2 \mathrm{kcal} \mathrm{mol}^{-1}$ ) published earlier by Dewar et al. 22 From these results we can conclude that AMI seems best suited for calculations on sterically crowded conjugated inolecules and on sigmatropic hydrogen shifts.

17. M.J.S. Dewar, E.G. Zoebisch, E.F. Healy and J.J.P. Stewart, J. Am. Chem. Soc. 107, 3902 (1985).

18. M.J.S. Dewar and W. Thiel, J. Am. Chem. Soc. 99,4899 (1977).

19. R.C. Bingham, M.J.S. Dewar and D.H. Lo, J. An. Chem. Soc. 97,1285 (1975).

20. "Moleculur Structure by Diffraction Methods". The Chemical Soclety, Burlington House, Paddington, London, vol. 1, pp 60-7 (1973).

21. W.R. Roth and f. Konig, Liebigs Ann. Chem. 699, 24 (1966).

22. M.J.S. Dewar, K.M. Merz, Jr. and J.J.P. Stewar, J. Chem. Soc., Chem. Commun. 166 (1985).

23. "ORTEP", Report ORNL 3794, C.K. Johnson, Oak Ridge National Leboratory, Oak Ridge, TN (1965).

24. G. Oermin, P. Muin and M.M. Wootfson, Acta Crystallogr., Sect. A 27, 368 (1971).

25. "ORFL", Ropor ORNLTM-305, W.R. Busing, K.O. Martin and H.A. Levy, Onk Ridge National Laboratory, Oek Bidre, TN (1962).

26. "International T ables for X-ray Crystallography", Kynoch Press, Birmingham, vol. IV, PP $72-98$ (1974).

27. R.F. Stewart, E.R. Davidson and W.T. Simpson, J. Chem. Phys. 42, 3175 (1965). 